\title{
PELAKSANAAN PROGRAM PEMBERDAYAAN MASYARAKAT MELALUI BADAN USAHA MILIK DESA
}

\author{
${ }^{1}$ Ita Nur Layyinatush Shifa, ${ }^{2}$ Ilyas \\ ${ }^{1,2}$ Jurusan Pendidikan Luar Sekolah, FIP, Universitas Negeri Semarang \\ Gedung A2 Kampus Sekaran Gunungpati Tlp. 8508019 Semarang 50229 \\ tattashiffa@gmail.com
}

\begin{abstract}
Abstrak
Tujuan dari penelitian ini adalah untuk mendeskripsikan pelaksanaan program pemberdayaan masyarakat melalui badan usaha milik desa di desa Lerep kecamatan Ungaran Barat kabupaten Semarang, hasil pelaksanaan program pemberdayaan masyarakat melalui badan usaha milik desa di desa Lerep kecamatan Ungaran Barat kabupaten Semarang, dan faktor penghambat dan pendukung pelaksanaan program pemberdayaan masyarakat melalui badan usaha milik desa di desa Lerep kecamatan Ungaran Barat kabupaten Semarang. Penelitian ini menggunakan pendekatan kualitatif dengan metode wawancara, observasi, dan dokumentasi dalam pengumpulan datanya. Keabsahan data menggunakan metode triangulasi sumber dan metode. Hasil penelitian menunjukkan adanya (1) pelaksanaan program pemberdayaan masyarakat BUMDES melalui program pariwisata, dalam pemanfaatan sumber alam sebagai tempat wisata, pemanfaat rumah warga sebagai homestay, (2) hasil pelaksanaan program pemberdayaan masyarakat BUMDES, berupa peningkatan pendapatan warga, perbaikan lingkungan fisik daerah, (3) faktor penghambat dan pendukung pelaksanaan program pemberdayaan masyarakat BUMDES yaitu kurangnya modal dan keterbatasan alat-alat oprasional, dalam menunjang kegiatan program. namun dalam mendukung berjalannya program masyarakat memiliki partisipasi yang baik.
\end{abstract}

Kata kunci: Pelaksanaan, Program, Pemberdayaan Masyarakat, BUMDES.

\section{Abstract}

The purpose of this study was to describe the implementation of community empowerment programs through village-owned enterprises in Lerep village, Ungaran Barat sub-district, Semarang district, the results of the implementation of community empowerment programs through village-owned enterprises in Lerep village, Ungaran Barat sub-district, Semarang district, and inhibiting factors and supporting implementation. community empowerment program through village-owned enterprises in Lerep village, Ungaran Barat district, Semarang district. This study uses a qualitative approach with interview methods, observation, and documentation in data collection. Data validity uses source and method triangulation methods. The results showed (1) the implementation of BUMDES community empowerment programs through tourism programs, in the use of natural resources as tourist attractions, benefiting residents 'houses as homestays, (2) the results of the implementation of the BUMDES community empowerment program, in the form of increased citizens' income, improvement of the physical environment of the region, (3) inhibiting and supporting factors for the implementation of the BUMDES community empowerment program, namely the lack of capital and limited operational tools, in supporting program activities. but in supporting the running of the program the community has good participation.

Keywords: Implementation, Program, Community Empowerment, BUMDES

\section{PENDAHULUAN}

Indonesia merupakan negara kepulauan kaya akan sumber alam hayati maupun nonhayati. Sumber daya alam hayati yang dimaksud berupa tumbuhan, pertanian dan perkebunan, hewan, pertenakan dan perikanan. Dari sumber alam tersebut, Indonesia memiliki potensi yang dapat dimanfaatkan untuk memenuhi kebutuhan hidup manusia. Karena alam merupakan segalanya untuk mata pencaharian, terutama untuk masyarakat perdesaan. 
Mayoritas masyarakat desa menggantukan hidup dari hasil potensi alam yang ada didaerahnya. Mesikpun potensi alam belum optimal dalam pemanfaatannya. Upaya dari pemerintah dalam mengoptimalkan potensi, salah satunya dengan menciptakan program pemberdayaan.

Widanti, (2011: 52-53) mengungkapkan pemberdayaan masyarakat merupakan upaya mempersiapkan masyarakat seiring dengan langkah upaya memperkuat kelembagaan masyarakat agar mereka mampu mewujudkan kemajuan, kemandirian, dan kesejahteraan dalam suasana keadilan sosial yang berkelanjutan. Untuk itu, pemberdayaan masyarakat merupakan upaya meningkatkan harkat dan martabat lapisan masyarakat yang saat ini dalam kondisi tidak mampu melepaskan diri dari perangkap kemiskinan dan keterbelakangan. Dengan kata lain, pemberdayaan adalah upaya memampukan dan memandirikan masyarakat. Sianipara, dkk, (2012) dalam jurnal internasionalnya menyatakan sebagai berikut :

"Empowerment should be the ultimate goal of any community development projects. While development often interpreted as the flow of resources from outside into community, empowerment pushand-pull full participation of all community members to change their world by themself, from inside to outside [2]. Speer and Hughey [6] concluded that community organization is an important way to reach empowerment."

Budiono : 2015 mengungkapkan upaya mendorong pembangunan ditingkat desa, pemerintah memberikan kewenangan kepada pemerintah desa untuk mengelola daerahnya secara mandiri, salah satunya adalah melalui lembaga ekonomi yang berada ditingkat desa yakni Badan Usaha Milik Desa. Lembaga berbasis ekonomi ini menjadi salah satu program yang dijalankan desa sebagai sarana untuk meningkatkan Pendapatan Asli Desa (PADes). Peranan BUMDES sebagai instrumen penguatan otonomi desa dan juga sebagai instrumen kesejahteraan masyarakat. BUMDES sebagai instrumen otonomi desa maksudnya adalah untuk mendorong pemerintah desa dalam mengembangkan potensi desanya sesuai dengan kemampuan dan kewenangan desa.

Desa Lerep mempunyai potensi sumber daya alam yang banyak, seperti pertanian, perkebunan, pertenakan, dan wisata alam, yang dapat di manfaatkan oleh masyarakat setempat. Karena sebagian besar masyarakat desa lerep merupakan petani, masyarakat memanfaatkan lahan dengan menanam padi, jagung, singkong. Dan pohon durian. Dalam bidang pertenakan hampir setiap kepala keluarga di dusun Indrokilo memiliki pertenakan sapi perah, yang berproduksi setiap hari, untuk diambil susunya, yang nanti hasilnya akan dijual. Wisata alam di desa Lerep sudah terkenal hingga masyarakat luar, dimana berbagai pilihan wisata yang banyak, seperti curug, embung, wisata edukasi, dan lain sebagainya

\section{KAJIAN TEORI}

BUMDES Gerbang Lentera merupakan sebuah Badan Usaha Milik Desa Lerep, Kecamatan Ungaran Barat, Kabupaten Semarang yang berdiri pada tahun 2016. Memiliki tujuh program unggulan, yaitu, LKM (lembaga keuangan masyarakat), Industri kecil, Periwisata, Perikanan, Pelayanan umum, Perdagangan umum, dan Penyewaan. Program Badan Usaha Miliki Desa, ditetapkan melalui musyawarah desa, dimana program ini dipilih sendiri oleh masyarakat berdasarkan keadaan lingkungan juga potensi yang dimiliki, untuk dimanfaatkan dalam meningkatkan perekonomian. BUMDES di Desa Lerep masih terbilang baru, namun 
program yang dimiliki sudah mulai berjalan, berbeda dari BUMDES di desa lain yang ada di kecamatan Ungaran Barat yang sudah terbentuk sejak lama. Dilihat dari program pariwisata, wisata alam di desa Lerep sudah banyak diketahui oleh pengunjung wisata yang datang dari luar desa hingga luar provinsi, begitu juga dengan program lainnya. Selain program yang sudah dikenal oleh masyarakat luar, Badan Usaha Milik Desa (BUMDes) Lerep, kerap dijadikan study banding oleh pihak pemerintah luar daerah.

Pertumbuhan ekonomi merupakan masalah perekonomian suatu negara dalam jangka panjang menuju keadaan yang lebih baik selama periode tertentu dan dapat dikaitkan juga sebagai keadaan kenaikan kapasitas produksi suatu perekonomian yang diwujudkan dalam bentuk pendapatan nasional, (Ernita, dkk. 2013). Sebelum BUMDES berdiri bidang perekonomian di desa Lerep masyarakat masih mengandalkan penghasilan buruh. Belum adanya pelayanan umum yang memudahkan warga masyarakat dalam arah pembayaran pajak dan lainnya. Potensi alam dan kearifan budaya lokal belum terlalu terekspor, sehingga hanya warga masyarakat desa Lerep yang dapat menikmati, padahal jika dapat dimanfaatkan, kearifan lokal dapat menjadi daya tarik tersendiri, untuk minat dari pengunjung. Terbentuknya BUMDES agar meningkatkan pendapatan asli desa, melayani masyarakat sesuai kebutuhannya, pemanfaatan sumber alam dapat dikelola dengan optimal. Melalui program program BUMDES diharapkan mampu untuk mencapai tujuan tersebut.

\section{METODE PENELITIAN}

Penelitian ini menggunakan metode penelitian kualitatif deskriptif karena penelitian ini bermaksud mendeskripsikan tentang pelaksanaan program pemberdayaan masyarakat melalui badan usaha milik desa di desa Lerep kecamatan Ungaran Barat kabupaten Semarang. Menurut Moleong (2010:6) penelitian kualitatif adalah penelitian yang bermaksud untuk memahami fenomena dengan cara deskripsi dengan bentuk kata-kata dan bahasa, pada suatu konteks khusus yang alamiah dan dengan memanfaatkan berbagai metode ilmiah. Lokasi penelitian yaitu di Desa Lerep Kecamatan Ungaran Barat kabupaten Semarang. Penentuan lokasi di Desa Lerep dikarenakan program pemberdayaan BUMDES sudah mulai berjalan.

Adapun subjek penelitian dalam penelitian ini ada 3 orang, yaitu Kepala BUMDES, Ketua program pariwisata dan industri kecil, di Desa Lerep Kecamatan Ungaran Barat. Kabupaten Semarang. Serta 3 orang informan yaitu warga masyarakat yang ikut dalam kegiatan program. Sumber data diambil dari data primer dan sekunder, di mana data primer diambil dari hasil wawancara dengan subjek penelitian, sedangkan data sekunder diambil dari dokumentasi yang berupa arsip-arsip, foto kegiatan dari pelaksanaan program pemberdayaan masyarakat BUMDES, dan referensi lain.

Pengumpulan data dilakukan melalui observasi, wawancara dan dokumentasi. Observasi digunakan untuk memperoleh data tentang kondisi fisik daerah penelitian dan pelaksanaan program pemberdayaan masyarakat BUMDES di desa Lerep. Wawancara dilakukan untuk menggali informasi dari berbagai sumber yaitu subjek maupun informan tentang pelaksanaan program pemberdayaan masyarakat melalui badan usaha milik desa di desa Lerep kecamatan Ungaran Barat Kabupaten Semarang. Serta metode dokumentasi yang merupakan pelengkap dari penggunaan metode observasi dan wawancara dalam penelitian 
kualitatif. Sugiyono (2010: 89) mengungkapkan bahwa analisis data adalah proses mencari dan menyusun secara sistematis data yang diperoleh dari hasil wawancara, catatan lapangan, dan dokumentasi, dengan cara mengorganisasikan data ke dalam kategori, menjabarkan ke dalam unit-unit, melakukan sintesa, menyusun ke dalam pola, memilih mana yang penting dan yang akan dipelajari, dan membuat kesimpulan sehingga mudah difahami oleh diri sendiri maupun orang lain.

Rachman, (2015:201-204).mengungkapakan proses analisis data dilakukan sejak sebelum memasuki lapangan, selama di lapangan, dan setelah selesai di lapangan yang dilakukan melalui beberapa tahap, yaitu :

1. Reduksi data

Data yang diperoleh dari lapangan jumlahnya cukup banyak, oleh karena itu perlu segera dilakukan analisis data melalui reduksi data. Mereduksi data berarti merangkum, memilih hal-hal yang pokok, memfokuskan pada hal-hal yang penting, dicari tema dan polanya. Dengan demikian, data yang telah direduksi akan memberikan gambaran yang jelas, dan mempermudah peneliti untuk melakukan pengumpulan data selanjutnya, dan mencarinya bila diperlukan.

2. Penyajian data

Setelah data direduksi, langkah selanjutnya adalah menyajikan data. Penyajian data dapat dilakukan dalam bentuk uraian singkat, bagan, hubungan antar kategori, bagan alur, dan sejenisnya.

3. Penarikan simpulan dan verifikasi

Langkah berikutnya dalam analisis data adalah penarikan simpulan dan verifikasi. Simpulan awal yang dikemukakan masih bersifat sementara, akan berubah bila tidak ditemukan bukti-bukti yang kuat yang mendukung. Sebaliknya bila didukung oleh bukti-bukti yang kuat dan konsisten, maka kesimpulan yang dikemukakan merupakan kesimpulan yang kredibel. Simpulan merupakan temuan baru yang sebelumnya belum pernah ada. Temuan dapat berupa deskripsi atau gambaran suatu objek yang sebelumnya masih remang-remang atau yang masih gelap dan setelah dilakukan penelitian menjadi jelas, dapat berupa hubungan kausal atau interaktif, hipotesis atau teori.

Untuk pembuktian temuan atau hasil lapangan dilakukan pemeriksaan keabsahan data untuk pengecekan kebenaran hasil penelitian dengan menggunakan teknik triangulasi. Menurut Denzin (dalam Moleong, 2010:330) triangulasi adalah teknik pemeriksaan keabsahan data yang memanfaatkan sesuatu yang lain diluar data tersebut untuk keperluan pengecekan/ sebagai pembanding terhadap data itu. Dalam penelitian ini teknik keabsahan datanya menggunakan triangulasi sumber dan metode. Menurut Patton dalam Moleong (2010: 330), triangulasi dengan sumber berarti membandingkan dan mengecek balik derajat kepercayaan suatu informasi yang diperoleh melalui waktu dan alat yang berbeda dalam penelitian kualitatif.

\section{HASIL DAN PEMBAHASAN}

Dari hasil peneliti melakukan penelitian terhadap subjek-subjek yang terlibat dalam pelaksanaan program pemberdayaan masyarakat melalui badan usaha milik desa di desa Lerep, kecamatan Ungaran Barat, Kabupaten Semarang, maka peneliti menemukan penelitian sebagai 
berikut. Badan usaha milik desa merupakan lembaga usaha desa yang dikelola mas yarakat dan pemerintah desa. Pendirian badan usaha milik desa disepakati melalui musyawarah desa, dengan berdasarkan pada kebutuhan dan potensi desa, guna meningkatkan kesejahteraan masyarakat desa melalui pendapatan asli desa. Pada tahun 2015 pemerintah desa mengharuskan setiap desa untuk membentuk badan usaha milik desa (BUMDES), yang didukung dalam Permen desa no 4 tahun 2015, tentang pendirian Badan Usaha Milik Desa yang dipersingkat menjadi BUMDES. Terbentuknya BUMDES sebagai upaya menampung seluruh kegiatan dibidang ekonomi dan pelayanan umum yang dikelola oleh desa atu kerjasama antar-desa. Dengan tujuan dapat meningkatkan perekonomian, pengoptimalan aset desa agar bermanfaat, meningkatkan usaha masyarakat, meciptakan peluang, pendapatan asli desa.

Badan usaha milik desa Lerep atau BUMDES dibentuk pada tanggal 23 Desember 2016, melalui musyawarah desa. Mulai diresmikan dan berjalan pada tanggal 1 Maret 2017 dan tercatat pada pusat pada tanggal 8 Maret 2017. Dengan lokasi kantor BUMDES Lerep terletak pada dusun Soka, jalan Kalimasada raya no 157 Lerep, kecamatan Ungaran Barat Kabupaten Semarang. Gerbang Lentera merupakan motto yang digunakan BUMDES desa Lerep dengan memiliki makna Gerakan Pembangunan Lerep Tentram dan Sejahtera.

Badan usaha milik desa Lerep memiliki tujuh program yang terbentuk, tujuh program tersebut yaitu:

1. LKM merupakan lembaga keuangan masyarakat desa di mana BUMDES mengajak para warga Desa Lerep untuk gemar menabung yang dapat dijadikan investasi keuangan bagi warga masyarakat untuk kehidupan yang akan datang, karena dari hasil menabung ini keuntungan sepenuhnya digunakan untuk kesejahteraan anggotanya.

2. Industri kecil / Catering yang dikelola BUMDES melayani baik pesanan lokal maupun luar desa. Bahkan menyebarkan leaflet-leaflet paketan catering ke beberapa instansi pemerintahan. Catering ini dikerjakan oleh warga desa Lerep, selain itu catering juga merangkul warga yang sudah memiliki usaha catering kecil akan diajak untuk bekerja sama.

3. Penyewaan Teratak dan sound sistem ini memang punya desa Lerep murni tapi di manfaatkan oleh BUMDES dengan bekerja sama dalam pemasaran maupun penyewaan. Jadi semua yang bekerja dalam penyewaan ini adalah pihak BUMDES dan alat yang tersedia milik desa di mana nanti hasilnya di bagi dua belah pihak ini.

4. Pariwisata di Desa Lerep terkenal banyak tempat untuk wisata, seperti embung sebligo yaitu penampungan air yang dimanfaatkan untuk pertanian warga, selain itu embung ini juga dimanfaatkan menjadi tempat pariwisata yang dikelola oleh BUMDES, dengan dibuat sebagai permainan air, pemandangan ikan nila, selain itu ada wisata edukasi dimana, wisatawan bisa belajar untuk menanam disawah, dan memeras susu sapi.

5. Pedagaangan umum/Bank sampah memiliki sistem dengan warga mengirim limbah kepada bank sampah yang mana setiap barang yang mereka kirim ditimbang dan di buatkan semacam buku tabungan sampah yang dapat mereka ambil setiap saat lebaran atau setahun sekali. Di bank sampah limbah dibedakan menjadi dua, yaitu limbah bersih (botol, plastik dan sebagainya) yang nantinya akan menjadi tabungan warga, dari pihak bank sampah mengumpulkan terlebih dahulu kemudian dijual pada pengepul limbah. Yang 
kedua limbah kotor yang nantinya akan diambil oleh pengelola dari warga melalui mobil BUMDES untuk dibuang ke TPS.

6. Pelayanan umum / Warseda (warung serba ada), melayani jasa pembayaran listrik, telepon, PBB secara online. BUMDES Gerbang Lentera bekerja sama dengan Bank BPD wilayah kerja Kabupaten Semarang untuk menangani di desa Lerep ini. Warseda (warung serba ada) yang menyediakan 9 bahan pokok yang nantinya dijual kepada warga dengan harga terjangkau.

7. Perikanan, merupakan budidaya ikan nila yang ditempatkan di embung sembligo.

Pemberdayaan masyarakat sebagai salah satu tema sentral dalam pembangunan masyarakat seharusnya diletakkan dan diorientasikan searah dan selangkah dengan paradigma baru pendekatan pembangunan. Paradigma pembangunan lama yang bersifat top-down perlu direorientasikan menuju pendekatan bottom-up yang menempatkan masyarakat di pedesaan sebagai pusat pembangunan (Aritonang, dalam Rahmat, 2015).

Pemberdayaan masyarakat dapat diwujudkan dalam berbagai program salah satunya adalah program desa wisata. Pengembangan Desa Wisata sebagai program Pemberdayaan masyarakat dimaksudkan untuk memberikan daya sekaligus sebagai salah satu upaya dalam penanggulangan kemiskinan di suatu daerah dengan mengolah potensi lokal yang ada di daerah tersebut. Sehingga dengan melalui Desa Wisata tersebut masyarakat diuntungkan melalui banyaknya wisatawan yang masuk. Adanya program desa wisata akan memberikan manfaatmanfaat yang berguna untuk meningkatkan taraf kehidupan masyarakat didalamnya, (Mustangin, dkk, 2017).

Community empowerment is an important part of capacity development where its community members decide on the goals and strategies for disaster risk management, contribute some, if not all, of the resources needed, and monitor their performance, (Hod, dkk. 2017)

Pemberdayaan BUMDES merupakan proses pemberdayaan potensi-potensi pembangunan yang ada di desa yang bersumber dari, oleh, dan untuk masyarakat atau dengan kata lain dilaksanakan secara partisipatif (Sayuti : 2011). Salah satu program BUMDES dalam pemberdayaan yaitu program pariwisata. Program pariwisata dibentuk dengan potensi alam yang dimiliki desa Lerep dapat dimanfaatkan sebagai tempat wisata. Selain potensi alam, potensi seni budaya atau tradisi yang ada di desa Lerep dapat dijadikan daya tarik bagi wisatawan untuk menikmati kearifan lokal yang tidak semua daerah masih mempertahankannya, karena faktor jaman yang sudah menjuru kearah modern sehingga meninggalkan tradisi-tradisi jaman dahulu.

Program pariwisata dibentuk pada akhir tahun 2016 bersamaan terbentukanya BUMDes. Program pariwisata terbentuk dikarenakan potensi alam yang dimiliki desa Lerep dapat dijadikan wisata, namun belum berjalan maksimal pemanfaatannya. Pada peresmian BUMDES tahun 2017 desa lerep dinobatkan sebagai desa wisata. Desa lerep memiliki tempat wisata alam yang belum terjangkau atau terekspor oleh masyarakat luar, sehingga hanya masyarkat desa Lerep yang menikmatinya. Bermula pada wisata alam yang belum maksimal pemanfaatanya, kemudian kepala desa lerep mengusulkan untuk membentuk program 
pariwisata guna mengelola wisata alam dan dijadikan penambahan penghasilan sebagai peningkatan pendapatan aseli desa. Dengan persetujuan masyarakat program pariwisata terbentuk. Dalam terbentuknya program ini mulailah partisipasi masyarakat bergotong royong, bahu membahu memperbaiki dan memperindah lingkungan yang nantinya akan dijadikan tempat wisata, juga nantinya digunakan untuk menarik pengunjung.

Wisata yang berada di desa Lerep ialah curuk indrokilo, embung sembligo, wisata watu gunung, kampung seni, dan balai lerep indah, selain memanfaatkan wisata alam, pariwisata juga memiliki program wisata yang ditawarkan pada pengunjung berupa paket wisata edukasi, paket wisata edukasi ini memiliki kegiatan yang ditawarkan kepada para wisatawan seperti menanam padi, menanam cabai, pembuatan permen susu, pembuatan sabun susu, pembuatan souvenir dari limbah, juga permainan menangkap bebek, menangkap ikan dan game kebersamaan. Paket wisata dikenai biaya bervairiasi mulai Rp. 30.000 hingga Rp. 75.000, bergantung pada pemilihan paket yang dipilih oleh para wisatawan, dengan jumlah minimal 30 orang yang mengikuti kegiatan.

Selain paket wisata, program pariwisata juga memfasilitasi homestay jika pengunjung ingin menginap. Homestay merupakan tempat menginap dengan memanfaatkan rumah warga dusun Lerep yang memang sengaja disewakan untuk kegiatan pariwisata, setiap permalam biaya menginap dikenai Rp. 20.000 hingga 40.000 perorang.Sejauh ini rumah warga yang disewakan berjumlah kurang lebih sekitar 50 rumah yang ada di Dusun Lerep. Untuk kebutuhan jumlah yang digunakan sekali menginap bergantung pada jumlah pengunjung yang ingin menggunakan fasilitas homestay.

Tourism plays a significant role in the economies of developing countries, including Indonesia. It has the potential to generate employment and income for the local communities, and promises to protect and preserve the natural and cultural heritage. Society plays a very important role in tourism. Community empowerment is one of the pillars in tourism development strategy. With the hope of the community to host tourists visiting the region. Efforts to improve community empowerment include activities to increase tourism awareness and business potential of the community in the field of tourism. Community empowerment based on local wisdom is done by involving the community so as to give empowerment for local people in tourism activities, (Cahyaningrum, 2017).

Peluang sektor pariwisata cukup prospektif, karena selain sebagai salah satu penghasil pertumbuhan ekonomi, sektor ini diharapkan dapat menjadi pendorong pertumbuhan sektor pembangunan lainnya, seperti sektor perkebunan, pertanian, perdagangan, perindustrian dan lain-lain, (Saepudin, dkk, 2017). BUMDES memiliki program industri kecil yang bergerak pada jasa catering. Catering merupakan usaha miliki warga masyarakat desa Lerep, yang sudah terbentuk untuk menghasilkan tambahan pendapatan. Usaha catering merupakan bisnis rumahan yang menyediakan jasa pembuatan hidangan besar maupun kecil yang dibutuhkan oleh konsumen yang memesan. Catering memiliki biaya rendah dan terjangkau, yang mengandalkan promosi mulut ke mulut atau media lainnya dalam mempromosikannya. 
Program industri kecil merupakan program BUMDES dengan merangkul usaha kecil rumahan di desa Lerep khususnya di dusun Soka. Industri kecil bergerak pada bidang usaha katering. Usaha katering ialah usaha yang sudah dimiliki sejak lima tahun yang lalu atau pada tahun 2013, dan bergabung pada BUMDES pada tahun 2017. Modal awal katering untuk belanja kebutuhan bahan memasak atau cepat habis masih menggunakan dana mandiri, sedangkan untuk perlengkapan seperti dus makanan, sendok dan semacamnya dimodali oleh BUMDES. Setiap pemesanan makanan dipatok harga Rp. 12.500 hingga Rp. 20.000 per dus, bergantung pada menu yang diminta oleh pemesan untuk nasi kotak dan snack mematok harga Rp. 6000- Rp.10.000 per dus untuk setiap variannnya.

Industri kecil mempunyai kedudukan, potensi dan peranan yang sangat strategis dalam mewujudkan tujuan pembangunan nasional. Mengingat peranannya dalam pembangunan, industri kecil harus terus dikembangkan dengan semangat kekeluargaan, saling isi mengisi, saling memperkuat antara usaha kecil dan besar dalam rangka pemerataan serta mewujudkan kemakmuran yang sebesar-besarnya bagi seluruh rakyat Indonesia. Untuk mewujudkan tujuan tersebut, pemerintah dan masyarakat harus bekerjasama. Masyarakat sebagai pelaku utama pembangunan, sedangkan pemerintah berkewajiban untuk mengarahkan, membimbing, melindungi serta menumbuhkan iklim usaha, (Ridwan, dkk. 2014)

Bisnis catering pada umumnya adalah bisnis lokal yang melayani hanya pasar lokal yang masih bisa dengan mudah dijangkau melalui angkutan darat. Hal ini dikarenakan sifat dari bisnis catering yang membutuhkan persiapan yang sangat intensif sebelum acara yang dilayani berlangsung. Di Indonesia, bisnis catering kebanyakan berasal dari bisnis rumahan, yang banyak mengandalkan promosi dari mulut ke mulut dari kenalan sendiri, atau pemasaran melalui brosur kepada calon pelanggan. Pemanfaatan sistem informasi yang dapat diakses secara online dapat meningkatkan pelayanan pelanggan maupun menjangkau pelanggan baru sehingga dapat meningkatkan kinerja bisnis, (Rohmalia dan Djajalaksana, 2013). Menurut Tim Delivery dalam Mardikanto dan Subianto (2012: 125) tahap pemberdayaan meliputi:

1. Seleksi lokasi/wilayah

Seleksi lokasi atau wilayah dilakukan sesuai dengan kriteria yang disepakati oleh lembaga, pihak-pihak terkait dan masyarakat. Penetapan kriteria penting agar pemilihan lokasi dilakukan sebaik mungkin, sehingga tujuan pemberdayaan masyarakat akan tercapai seperti yang diharapkan.

2. Sosialisasi Pemberdayaan Masyarakat

Sosialisasi, merupakan upaya mengkomunikasikan kegiatan untuk menciptakan dialog dengan masyarakat. Melalui sosialisasi akan membantu untuk meningkatkan pemahaman masyarakat dan pihak terkait tentang program dan atau kegiatan pemberdayaan masyarakat yang direncanakan.

Seleksi lokasi dilakukan untuk menetukan letak yang tepat untuk program tersebut berjalan, dengan melihat kebutuhan masyarakat dan potensi yang sekiranya dapat mendukung program dapat berjalan. Sosialisasi dilakukan pada setiap pertemuan yang dirasa perlu untuk menginformasikan terbentuknya program - program BUMDES, tentang pelaksanaan program yang akan dijalankan dan dikembangkan bersama-sama guna meberdayakan masyarakat. Sosialisasi adalah untuk memberikan informasi kepada warga tentang adanya program 
BUMDES yang akan melibatkan masyarakat. Sosialisasi dilakukan pada saat pertemuan antar warga di balai desa Lerep, selain itu sosialisasi dilakukan saat adanya perkumpulan PKK, dan saat sedang ada pertemuan lintas RT. Materi yang disampaikan lebih mendalam pada programprogram BUMDES, dan bagaimana partisipasi dari masyarakat dibutuhkan pada saat program berjalan.

Menurut Sumodiningrat dalam buku Mulyono (2017 : 44-45) proses belajar dalam rangka pemberdayaan masyarakat akan berlangsung secara bertahap. Menurut Sumodingnirat tahap-tahap yang harus dilalui tersebut meliputi ;

1. Tahap penyadaran dan pembentukan perilaku menuju perilaku sadar dan perduli sehingga merasa membutuhkan peningkatan kapasitas diri.

2. Tahap transformasi kemampuan berupa wawasan pengetahuan kecakapan-keterampilan agar terbuka wawasan dan memberikan ketrampilan dasat sehingga dapat mengambil peran didalam pembangunan.

3. Tahap peningkatan peningkatan kemampuan intelektual dan kemampuan inovatif untuk mengantarkan pada kemandirian. Pada tahap ketiga ini merupakan tahap pengayakan atau peningkatan intelektualitas dan kecakapan keterampilan yang diperlukan, supaya mereka dapat membentuk kemampuan kemandirian.

Program pariwisata dalam tahap proses pemberdayaan ini, masyarakat memiliki kesadaran dan kepedulian setelah diberikan arahan saat sosialisasi program-program BUMDES. Keterampilan yang dimiliki masyarakat berasal dari pelatihan yang diberikan oleh kementerian Deputi dan Dinas Pariwisata, dengan mengadakan pelatihan homestay dan pemandu wisata. Kemampuan yang dimiliki dapat mengembangkan homestay secara mandiri, mampu menyumbangkan tenaga maupun material dalam program pariwisata.

Program industri kecil dalam tahap proses pemberdayaan, masyarakat sudah memiliki kesadaran dikarenakan usaha catering sudah dibentuk sebelum bergabungnya di BUMDES, namun kesadaran diarahkan kembali pada saat sosialisasi. Keterampilan yang dimiliki berasal dari warga masyarakat sendiri, dikarenakan belum adanya pelatihan yang dilakukan untuk inovasi baru dalam usaha catering. Dalam peningkatan kemampuan usaha catering terletak pada pegelolaan berproduksi, meningkatnya jumlah pesanan dan bidang promosi. Hasil pelaksanaan program pemberdayaan, memiliki dampak pada bidang ekonomi. Terjadinya peningkatan pendapatan yang semula hanya mendapatkan pendapatan dari pekerjaan buruh, sekarang mendapatkan tamabahan dari hasil penyewaan homestay berkisaran Rp.30.000 hingga Rp.300.000 permalam / perorang, tiap tahunnya pada program pariwisata. Sedangkan industri kecil Peningkatan pendapatan meskipun dalam jumlah kecil, yang didapat Rp.50.000 setiap kali berproduksi. Peningkatan dalam media promosi, yang sudah mulai merambah melalui website untuk menarik pengunjung untuk mengetahui kagiatan dan apa saja yang dapat diikuti di desa Lerep. Perbaikan kondisi lingkungan berupa perbaikan jalan dan fasilitas umum lainnya.

Pemberdayaan di Bidang Usaha Ekonomi pada Badan Pemberdayaan Masyarakat pada dasarnya harus dilaksanakan secara optimal dan terarah agar dapat memperbaiki keadaan ekonomi sekaligus mampu mengangkat kondisi ekonomi masyarakat miskin yang ada. Dengan 
memberikan kewenangan dan kekuatan kepada masyarakat untuk mengakses sumber daya ekonomi yang tersedia secara optimal, sehingga mereka diharapkan dapat berdaya dalam memperbaiki kemampuan ekonomi mereka agar dapat memenuhi kebutuhan dasar mereka secara mandiri, (Kurniawati, dkk. 2010). Faktor-faktor yang menghambat dalam pelaksanaan program pemberdayaan masyarakat BUMDES, Kurangnya modal dalam pengelolaan program, sehingga masih menggunakan uang iuaran mandiri, alat - alat penunjang kegiatan berproduksi program masih miliki sendiri dan seadanya. Faktor yang mendukung berjalanya program Partisipasi masyarakat dalam berproduksi serta bantuan tenaga dan material.

Faktor penghambat merupakan sesuatu atau hal-hal yang dapat menghalangi atau bahakan mengehentikan kemajuan atau pencapaian suatu hal. Dalam pelaksanaan program pemberdayaan salah satu yang menjadi hambatan berjalanya program adalah dana. Dana merupakan uang yang disediakan untuk suatu keperluan menurut KBBI. Faktor pendorong adalah hal-hal yang memengaruhi sesuatu menjadi berkembang, memajukan, menambah dan menjadi lebih dari sebelumnya. Salah satu faktor pedukung dalam berjalannya pelaksanaan progam BUMDes ialah partisipasi yang dilakukan masyarakat, dimana masyarakat bergotongroyong, ikutserta dalam melancarakan program yang telah dibentuk. Partisipasi merupakan bagian penting dari budaya bangsa kita yang senantiasa menempuh pendekatan musyawarah untuk mufakat dalam mencari jalan keluar serta pengambilan keputusan bersama. Dengan kata lain, apapun yang menjadi hasil ataupun keputusan musyarawah mufakat tersebut sudah menjadi tanggung jawab bagi semua peserta musyawarah dalam konteks ini adalah masyarakat, (Laely, 2015). Partisipasi masyarakat dalam berjalannya program yang dibentuk oleh BUMDES, memiliki antusias, warga sadar akan butuhnya keikutsertaan yang mengaharapkan partisipasi masyarakat untuk mendukung berjalannya program. Partisipasi masyarakat dapat dilihat dalam bergotong-royong memperbaiki lingkungan fisik bersama-sama.

\section{SIMPULAN DAN SARAN}

Berdasarkan hasil penelitian dan pembahasan dalam penelitian yang telah dilakukan, maka dapat disimpulkan bahwa BUMDES memiliki tujuh program yang dibentuk sesuai kebutuhan masyarakat dan potensi yang ada di desa Lerep. Setiap program dikembangkan oleh masing-masing unit. Seperti unit pariwisata selain memanfaatkan alam, unit pariwisata memiliki kegiatan paket wisata dan homestay yang dibentuk dengan memanfaatkan fasilitas dari masyarakat. Selain pariwisata, unit industri kecil yang bergerak dalam usaha catering memiliki peningkatan dalam berproduksi. Dalam pelaksanaan program tentu partisipasi masyarakat dibutuhkan karena masyarakat merupakan sasaran dalam pemberdayaan, dengan hasil masyarakat dapat berdaya, memandirikan diri secara inividual, maupun kelompok. Output atau hasil dalam pelaksanaan program pemberdayaan berupa peningkatan pendapatan masyarakat yang didapat dalam pelaksanaan program pemberdayaan setelah diberikan arahan atau pelatihan.

Kendala yang dialami dalam pelaksanaan program pemberdayaan ialah keterbatasan modal, dimana tambahan modal setiap unit program masih menggunakan dana mandiri. Meskipun memiliki kendala dalam pendanaan, namun salah satu faktor pendukung program 
pemberdayaan untuk tetap berjalan ialah partisipasi masyarakat yang sudah antusias dalam keikutsertaan pelaksanaan program, melalui tenaga, pikiran, ataupun material.

Setelah mendapatkan simpulan dan fakta di lapangan beberapa saran diajukan, berdasarkan hasil penelitian yang telah dilakukan ini, penulis sampaikan saran-saran sebagai berikut.

1. Bagi BUMDES perlu adanya peningkatan disetiap program pemberdayaan dengan memperhatikan apa saja yang masih dibutuhkan, karena beberapa program belum dapat berjalan seimbang, maka perlunya upaya pengembangan yang memiliki jangka.

2. Bagi Program Pemberdayaan perlu adanya peningkatan dan pengembangan lagi dalam pengelolaan program. pengembangan dalam media promosi dengan memanfaatkan teknologi informasi seperti media sosial dengan tatanan yang menarik.

3. Bagi Program Industri Kecil, perlu adanya pelatihan untuk memberikan keterampilan dan inovasi-inovasi pada setiap menu. Dapat menjalin kerjasama dengan sebuah perusahaan agar pembuatan produk dapat diproduksi secara produktif. Peningkatan promosi tidak hanya diluar desa namun diluar kota maupun kabupaten melalui pemanfaatan teknologi yang sekarang sudah berkembang, seperti media sosial media instragram yang dapat membantu pemasaran, berkembang pada penjualan online.

4. Bagi Masyarakat untuk lebih meningkatkan partisipasi meskipun sudah memiliki antusias yang baik, namun tetap memberikan ide yang dapat dikembangankan dalam berjalanya program pemberdayaan, sehingga muncul inovasi - inovasi baru.

\section{DAFTAR PUSTAKA}

Budiono, Puguh. 2015. Jurnal Politik Muda. Implementasi Kebijakan Badan Usaha Milik Desa(Bumdes) Di Bojonegoro 4 (1) : 116 -125.

Cahyaningrum, Dinis. 2017. International Journal Of Scientific \& Technology Research. Community Empowerment Based Local Wisdom In Tourism Of Bajo Community, Wakatobi 6 (11) : 196-201.

Ernita, Dewi, dkk. 2013. Jurnal kajian ekonomi. Analisis Pertumbuhan Ekonomi, Investasi, Dan Konsumsi Di Indonesia. 1 (2) : 176-193.

Hod, Rozita, dkk. 2017. Universal Journal of Public Healty. Community Empowerment and the Associated Factors among the 2014 Flood Victims in Pahang. 5(3): 119-126.

Laily, Elida Imro'atin Nur. 2015. Jurnal Kebijakan dan Manajemen Publik. Partisipasi Masyarakat Dalam Perencanaan Pembangunan Partisipatif. 3 (3). 299-303.

Kurniawan, Daniel Teguh. Dkk. 2013. Jurnal Ilmu Pendidikan. Inovasi Pemberdayaan Masyarakat Perdesaan inovasi pemberdayaan masyarakat perdesaan studi kasus pada Unit pengelola kegiatan (upk) dalam pelaksanaan program Nasional pemberdayaan masyarakat-mandiri perdesaan (pnpmmpd) kecamatan wonosalam kabupaten demak $2(2): 1-12$. 
Mulyono, Sungkowo Edi. 2017. Kemiskinan Dan Pemberdayaan Masyarakat. Yogyakarta : Penerbit Ombak.

Mustangin, dkk. 2017. Jurnal Pemikiran dan Penelitian Sosiologi. Pemberdayaan Masyarakat Berbasis Potensi Lokal Melalui Program Desa Wisata di Desa Bumiaji. 2 (1) : 59-72.

Moleong. 2010. Metodologi Penelitian Kualitatif Edisi Revisi. Bandung: PT Remaja Rosdakarya.

Mardikanto, Totok \& Poerwoko Soebiato. 2012. Pemberdayaan Masyarakat. Bandung : Penerbit Alfabeta.

Ridwan, Muh., dkk. 2014. Jurnal Administrative Reform. Pembinaan Industri Kecil dan Menengah Pada Dinas Perindustrian, Perdagangan, Koperasi dan UMKM Kota Bontang. 2 (2) : 187-199.

Rahmat, Abdul. 2015. Jurnal Kependidikan. Dampak Pemberdayaan Masyarakat Melalui Pelatihan Pemanfaatan Enceng Gondok Dalam Meningkatkan Ekonomi Masyarakat Desa Lauwonu Di Kecamatan Tilango Kabupaten Gorontalo. 12 (1) : 1-12

Rachman, Maman. 2015. Lima Pendekatan Penelitian. Yogyakarta : Magnum Pustaka Utama. Saepudin, Encang, dkk. 2017. Jurnal Ilmu Sosial dan Humaniora. Karakteristik Pramuwisata Dalam Pengembangan Desa Wisata Agro Di Kabupaten Bandung Barat. 6 (1) : 51-59.

Sugiyono. 2015. Metode Penelitian Pendidikan. Bandung: Alfabeta.

Sayuti, H. Muh. 2011. Jurnal ACADEMICA Fisip Untad. Pelembagaan Badan Usaha Milik Desa (Bumds) Sebagai Penggerak Potensi Ekonomi Desa Dalam Upaya Pengentasan Kemiskinan Dikabupaten Donggala 3(2) : 717-728.

Sianipar, Corinthias Pamatang Morgana, dkk, 2012, Procedia Environmental Sciences, Community Empowerment Through Appropriate Technology: Sustaining The Sustainable Development 17 ( 2013 ) :1007-1016.

Widiastuti dkk. 2015. Pemberdayaan Masyarakat Marginal. Yogyakarta: Pustaka Pelajar.

Widanti, Ni Putu Trika, 2011, Model Kebijakan Pemberdayaan Perempuan Di Bali, Depansar : Jagatpress. 